\title{
Sex Differences in Risk and Resilience: Stress Effects on the Neural Substrates of Emotion and Motivation
}

\author{
(10) Cara L. Wellman, ${ }^{1}$ Debra A. Bangasser, ${ }^{2}$ Justin L. Bollinger, ${ }^{3}{ }^{-}$Laurence Coutellier, ${ }^{4}$ Marian L. Logrip, ${ }^{5}$ \\ - Kelly M. Moench, ${ }^{1}$ and ${ }^{\circ}$ Kimberly R. Urban ${ }^{6}$ \\ ${ }^{1}$ Department of Psychological and Brain Sciences, Program in Neuroscience, and Center for the Integrative Study of Animal Behavior, Indiana University, \\ Bloomington, Indiana 47405, 2Psychology Department and Neuroscience Program, Temple University, Philadelphia, Pennsylvania 19122, ${ }^{3}$ Department of \\ Pharmacology and Systems Physiology, University of Cincinnati College of Medicine, Cincinnati, Ohio 45237, ${ }^{4}$ Departments of Psychology and \\ Neuroscience, Ohio State University, Columbus, Ohio 43210, ${ }^{5}$ Department of Psychology, Indiana University-Purdue University Indianapolis, Indianapolis, \\ Indiana 46202, and ${ }^{6}$ Children's Hospital of Philadelphia, Abramson Research Center, Philadelphia, Pennsylvania 19104
}

Risk for stress-sensitive psychopathologies differs in men and women, yet little is known about sex-dependent effects of stress on cellular structure and function in corticolimbic regions implicated in these disorders. Determining how stress influences these regions in males and females will deepen our understanding of the mechanisms underlying sex-biased psychopathology. Here, we discuss sex differences in CRF regulation of arousal and cognition, glucocorticoid modulation of amygdalar physiology and alcohol consumption, the agedependent impact of social stress on prefrontal pyramidal cell excitability, stress effects on the prefrontal parvalbumin system in relation to emotional behaviors, contributions of stress and gonadal hormones to stress effects on prefrontal glia, and alterations in corticolimbic structure and function after cessation of chronic stress. These studies demonstrate that, while sex differences in stress effects may be nuanced, nonuniform, and nonlinear, investigations of these differences are nonetheless critical for developing effective, sex-specific treatments for psychological disorders.

Key words: corticolimbic regions; corticosterone; corticotropin releasing factor; parvalbumin; microglia

\section{Introduction}

Risk for psychopathology differs markedly in men and women. For instance, men are at increased risk for disorders, such as attention deficit hyperactivity disorder and schizophrenia (Ramtekkar et al., 2010; Mendrek and Mancini-Marie, 2016). Women are at increased risk for disorders such as depression and post-traumatic stress disorder (PTSD) (Breslau, 2009; Kessler et al., 2012), and often display more severe symptoms (de Graaf et al., 2002; Schoevers et al., 2003). One environmental factor linked to all of these disorders is stress. PTSD is precipitated by a traumatic event, and symptoms of depression, attention deficit hyperactivity disorder, and schizophrenia are exacerbated by stressor exposure (Newman and Bland, 1994; Hirvikoski et al., 2009). However, little is known about the sex-dependent effects of stress on corticolimbic regions implicated in these disorders (e.g., Bennett, 2011). Determining how stress influences corticolimbic functioning in males and females will deepen our knowl-

Received July 26, 2018; revised Sept. 20, 2018; accepted Sept. 22, 2018.

This work was supported by National Science Foundation Career Grant I0S-1552416 and Pennsylvania Department of Health Grant 420792 to D.A.B., National Institutes of Health Grants 5T32NS007413 and R01MH093981 to K.R.U., Grant AA021802 to M.L.L., Grants T32MH103213 and T32HD049336 to J.L.B. and K.M.M., and Grant UL1TR001108 to K.M.M. and C.L.W.

The authors declare no competing financial interests.

Correspondence should be addressed to Dr. Cara L. Wellman, Department of Psychological and Brain Sciences, Program in Neuroscience, and Center for the Integrative Study of Animal Behavior, 1101 East 10th Street, Indiana University, Bloomington, IN 47405. E-mail: wellmanc@indiana.edu.

DOI:10.1523/JNEUROSCI.1673-18.2018

Copyright $\odot 2018$ the authors $\quad 0270-6474 / 18 / 389423-10 \$ 15.00 / 0$ edge of brain-behavior relationships and the mechanisms underlying sex-biased disorders. This understanding is critical to developing effective, sex-specific treatments for these disorders.

Here, we provide examples of new data demonstrating sex differences in the neurobiological effects of stress across several corticolimbic structures and cognitive and emotional processes. We conclude with a discussion of the important themes that emerge from these studies, emphasizing that sex differences in the effects of stress are nuanced, nonuniform, and nonlinear.

\section{CRF regulation of arousal and cognition}

CRF, a key orchestrator of the stress response, can directly regulate corticolimbic regions, including the PFC, to alter anxiety and working memory (Jaferi and Bhatnagar, 2007; Hupalo and Berridge, 2016). In addition, CRF can alter midbrain and hindbrain monoaminergic and cholinergic nuclei. One consequence of this regulation is that these neurotransmitter systems, in turn, affect corticolimbic regions, influencing a range of behaviors from stress coping strategies to decision making (Wood et al., 2013; Bryce and Floresco, 2016). Recent comparisons indicate that female rodents are more sensitive to CRF's effects on noradrenergic-mediated arousal, whereas male rodents are more sensitive to the effects of CRF on cholinergic-mediated cognition (Bangasser et al., 2018).

Stress activates the locus ceruleus (LC)-norepinephrine arousal system via CRF. Specifically, CRF increases the firing rate of LC neurons to cause norepinephrine release into corticolimbic regions to heighten arousal (Valentino and Van Bockstaele, 
A

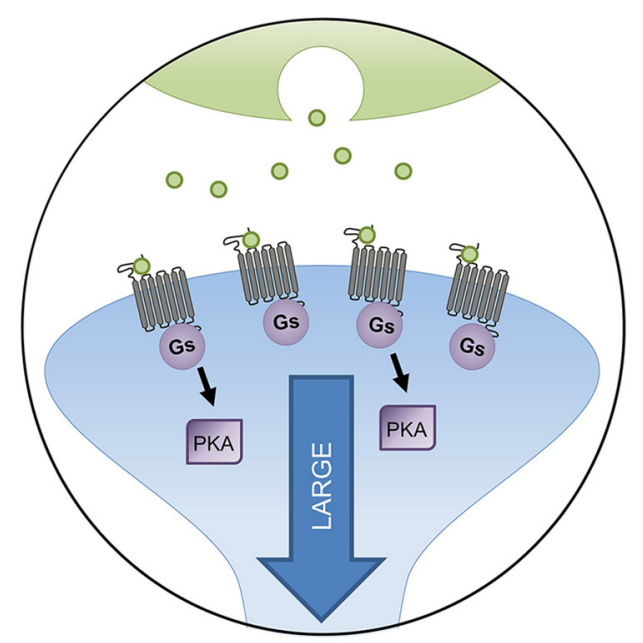

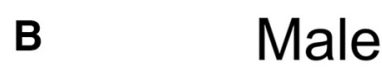

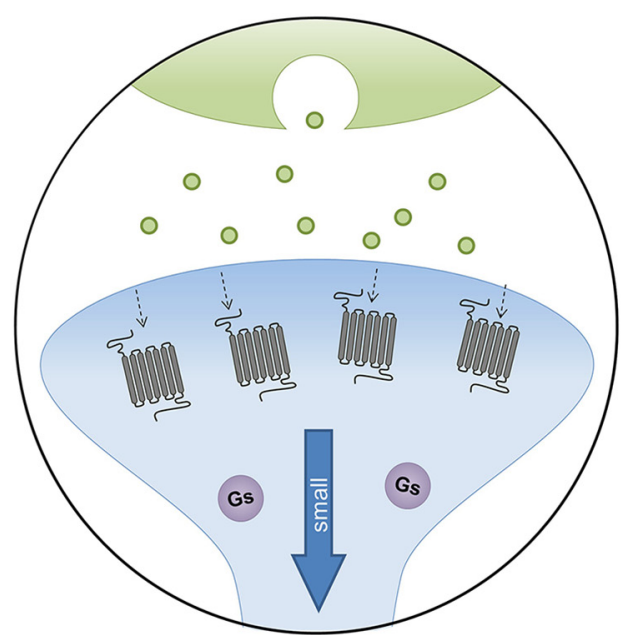

Figure 1. Sex differences in CRF, receptors in LC. $A$, In females, CRF 1 receptors bind to Gs and signal more through the cAMP-PKA pathway, but they do not internalize following stress and CRF overexpression, leading to a large $L C$ response to CRF. $B$, In males, $C_{1}$, receptors in $L C$ internalize following stress and CRF overexpression, resulting in a smaller response to CRF. Adapted with permission from Bangasser et al. (2018).

2005). There are sex differences in LC neuronal sensitivity to CRF, such that, compared with males, LC neurons in females respond to lower doses of CRF (Curtis et al., 2006; Bangasser et al., 2010). The LC contains $\mathrm{CRF}_{1}$ receptors, which are G-protein (guanine-nucleotide binding protein) coupled receptors that preferentially bind Gs (a type of G-protein) to activate the cAMPprotein kinase A (PKA) signaling pathway (Grammatopoulos et al., 2001). $\mathrm{CRF}_{1}$ receptor activation of the cAMP-PKA signaling pathway increases the firing rate of LC neurons (Jedema and Grace, 2004). In females, increased LC neuronal sensitivity to CRF results from greater $\mathrm{CRF}_{1}$ receptor coupling to Gs and, consequently, more activation of the cAMP-PKA pathway in females than males (Fig. 1) (Bangasser et al., 2010; Bangasser and Wicks, 2017). There are also sex differences in $\mathrm{CRF}_{1}$ receptor internalization, a process by which saturating concentrations of CRF cause receptors to be trafficked intracellularly, where they can no longer be activated. Stressor exposure and CRF hypersecretion induce $\mathrm{CRF}_{1}$ receptor internalization in male, but not female, LC neurons (Bangasser et al., 2010, 2013). This lack of internalization in females may render their LC neurons less adaptable to conditions of CRF hypersecretion, which have been reported in patients with PTSD and depression (Bremner et al., 1997; Heuser et al., 1998). Collectively, these studies reveal sex differences in $\mathrm{CRF}_{1}$ receptors in the $\mathrm{LC}$ that can bias females toward high arousal during stressful events. Hyperarousal symptoms, such as lack of concentration and sleep disturbance, are reported in PTSD and depression, disorders that are more common in women than men (Breslau, 2009; Kessler et al., 2012). Thus, if similar $\mathrm{CRF}_{1}$ receptor sex differences in the LC occur in humans, they may contribute to this female vulnerability.

The basal forebrain cholinergic system is also regulated by $\mathrm{CRF}$, and new findings are revealing sex differences in this regulation. One cognitive process mediated by this system is sustained attention, the ability to monitor situations for intermittent and unpredictable events (Sarter et al., 2001). Central administration of CRF disrupts sustained attention in both male and female rats (Cole et al., 2016). However, ovarian hormones modulate this effect, such that CRF impairs attention in females only when they are in estrous cycle stages with low levels of ovarian hormones.
Thus, ovarian hormones appear to be protective against the impairing effect of CRF on attention. Unlike females, males, who lack surges in ovarian hormones, would never benefit from their protective effects. Bangasser et al. (2016) are beginning to investigate the effects of CRF on the medial septum (MS) cholinergic system, which is critical for regulating hippocampal-dependent learning. A low dose of CRF in the MS disrupts spatial learning only in males, whereas a high dose impairs learning in both sexes (Bangasser et al., 2016). Thus, the male MS is more sensitive to CRF than is the female MS. The mechanisms that establish sex differences in CRF regulation of the basal forebrain cholinergic system are not yet well understood. However, this male vulnerability to CRF-induced cognitive deficits could contribute, perhaps in part, to the higher rates of attention deficit hyperactivity disorder and schizophrenia in men than in women (Ramtekkar et al., 2010; Mendrek and Mancini-Marie, 2016). These basic research studies highlight sex differences in CRF sensitivity that bias males and females toward different physiological responses to stress, and perhaps to different risks for psychiatric disorders in which symptoms are exacerbated by stress.

\section{Glucocorticoid modulation of amygdala activity and alcohol responsiveness}

Alcohol use disorder (AUD) is characterized by recidivism to alcohol use. While AUDs have historically been up to twice as prevalent in males relative to females (World Health Organization, 2014), this gender gap is narrowing (White et al., 2015). Stress is a prominent trigger for relapse (Sinha, 2013), and may, in part via the actions of glucocorticoids such as cortisol (corticosterone in rats), also accelerate the development of AUD (Blaine and Sinha, 2017). Importantly, women with AUD experience greater craving to drink following exposure to stressful images (Hartwell and Ray, 2013) and stronger relationships between past trauma severity and craving (Heffner et al., 2011), relative to men. Elucidating sex differences in neuronal responses to stressors and their impact on alcohol use is therefore crucial to developing novel treatments for both sexes.

Studies using females or both sexes to investigate stressalcohol interactions in rodent models have been limited. Female 
rodents may show increased (Cozzoli et al., 2014) or decreased (Chester et al., 2006, 2014) alcohol intake after stress, relative to males, which may vary based on stressor (Cozzoli et al., 2014) or age at stress exposure (Wille-Bille et al., 2017). Long-lasting effects of past stress on alcohol intake and relapse-like drinking have only been studied in males (Casey, 1960; Lynch et al., 1999; Logrip and Zorrilla, 2012; Logrip et al., 2014), although females display greater sensitivity to acute stress-induced reinstatement than do males (Bertholomey and Torregrossa, 2017). Females also show heightened sensitivity to corticosterone treatment throughout adolescence, which increased alcohol seeking in adulthood in both sexes but tended to affect females more (Bertholomey et al., 2016). Corticosterone may specifically regulate alcohol intake exacerbated by stress or anxiety, as glucocorticoid receptor antagonism blunted alcohol seeking or drinking in rats subsequent to stress or alcohol withdrawal (Simms et al., 2012; Vendruscolo et al., 2012). Importantly, blockade of corticosterone's actions only in the CeA replicated these effects (Simms et al., 2012; Vendruscolo et al., 2015).

Escalating alcohol intake over time shifts the motivation to drink toward alleviation of negative symptoms (Koob, 2015), and the CeA is integral to this transition. The CeA synthesizes inputs from amygdala subdivisions to regulate stress- and rewardrelated behavioral responses (Janak and Tye, 2015); thus, changes in the CeA and associated circuitry have a unique capacity to alter behavior. How the CeA differentially adapts to stressors, alcohol, and their co-occurrence in females versus males has been minimally explored. In males, alcohol acutely activates GABAergic and inhibits glutamatergic postsynaptic responses in the CeA, effects exacerbated during alcohol withdrawal (Roberto et al., 2003, 2004a,b). Stress similarly increases GABAergic responses in CeA of males (Ciccocioppo et al., 2014), suggesting overlap in the effects of alcohol and stress on CeA neurotransmission. Increased GABAergic and decreased glutamatergic responses should similarly alter the output of the CeA, implicating CeA neurons as a point of convergence for circuit adaptations to alcohol and stressors to produce maladaptive anxiety-like and alcohol-drinking behaviors. Yet these conclusions based on data collected in males fail to address possible sex differences in this circuitry.

Given the CeA's role in modulating anxiety-like and alcoholdrinking behavior and the stronger association between stress and alcohol intake in women, the CeA could be hypothesized as a site for greater synergistic adaptations to stress and alcohol in females. However, current data suggest that this is not the case. Instead, corticosterone and alcohol differentially altered glutamatergic EPSPs in response to activation of BLA inputs to the medial (CeM) and lateral (CeL) CeA in males versus females (Logrip et al., 2017). Alcohol acutely reduced BLA-evoked EPSP (BLA-EPSP) amplitudes in CeM and CeL neurons in males, whereas alcohol's effects on BLA-EPSPs were blunted in both subregions in females (Logrip et al., 2017; Kirson et al., 2018). BLA-EPSPs differed across estrous cycle phases in CeM neurons, indicating an interaction between hormonal status and alcohol responsiveness in females. Conversely, corticosterone treatment reduced BLA-EPSP amplitudes in CeL, but not CeM, in females, occluding the effects of alcohol coapplication in both subdivisions (Logrip et al., 2017). On the other hand, in males, corticosterone neither altered BLA-EPSPs nor changed alcohol's effects, as application of alcohol after corticosterone resulted in reductions in BLA-EPSP amplitudes similar to those produced by alcohol alone. These results demonstrate sex differences in sensitivity to corticosterone versus alcohol (as shown in Fig. 2) and highlight the necessity for understanding how stress and alcohol, as well as their interaction, differentially influence neuronal activity by sex in key nuclei regulating stress and drug responses.

\section{Stress and PFC}

Social stress and physiology of pyramidal neurons

The PFC regulates executive functions, including decisionmaking, judgment, behavioral inhibition, and cognitive flexibility (Goldman-Rakic, 1996; Arnsten and Li, 2005; Girotti et al., 2018). Impairments in executive function are symptoms of many stress-related psychological disorders (e.g., schizophrenia, depression, PTSD), implicating pathophysiology in the PFC in these disorders (e.g., Negrón-Oyarzo et al., 2016). Indeed, in males, chronic stress impairs performance on many tasks involving PFC, including fear extinction, behavioral flexibility, and working memory (Holmes and Wellman, 2009; Maren and Holmes, 2016).

Dendritic retraction and spine atrophy, neurochemical and physiological changes, and impairment of PFC-mediated behaviors are well-documented sequelae of chronic restraint or chronic variable stress in adult males (Farrell et al., 2013; Moench and Wellman, 2015). However, for humans, stressors are often of a social nature (i.e., bullying); thus, rodent social stressors (i.e., resident-intruder defeat) may provide better translational validity than restraint or shock stress. Social stress is particularly damaging during adolescence, as this is a period of dynamic growth and restructuring in the PFC (Lewis, 1997; Lenroot and Giedd, 2006; Koss et al., 2010, 2014). Social stress impaired strategyshifting of adolescent males only when they were tested as adults (Snyder and Valentino, 2015). Female adolescents were better at the task than adults, but stress impaired their reversal learning, indicating age- and sex-specific effects of social stress (Snyder et al., 2015).

Urban and Valentino (2017) used the resident-intruder stress paradigm to examine the effects of chronic social stress in male and female rats in early adolescence (PD 30-36), mid-adolescence/puberty (PD 42-46), or adulthood (PD 69-76). Stress impacts in mPFC were most striking at mid-adolescence, regardless of sex. Social stress reduced intrinsic excitability, measured as response to injected current, and also increased interspike interval, in mid-adolescents of both sexes, indicating slowed kinetics and reduced potassium channel function. In addition, social stress reduced the amplitude, but not frequency, of EPSPs, indicating reduced synaptic transmission via reduction of postsynaptic glutamate receptors (AMPAR and NMDAR). In addition, there were sex-dependent stress effects. For instance, social stress reduced intrinsic excitability and increased interspike interval in adult females, but not adult males. Sex-specific effects of stress were also noted in mid-adolescents. Stress increased input resistance, but lowered threshold to fire, in male mid-adolescents, but it increased the amplitude of afterhyperpolarization in female mid-adolescents. Stress also selectively reduced the amplitude of action potentials only in male mid-adolescents. These sexspecific effects implicate potassium channel alterations and suggest that social stress impacts potassium channel function differently in males and females, but these effects lead to the same outcome of reduced neuronal excitability. These results suggest reduced $\mathrm{mPFC}$ activity following social stress in mid-adolescents of both sexes and female adults but show that adult male mPFC is largely impervious to social stress. Given previous studies showing stronger impairments in PFC-mediated tasks following social stress in adolescence, the neuronal changes noted in this study 
provide a likely cellular correlate of impaired executive function that would allow for greater amygdalar drive and enhance the likelihood of psychiatric disorders in stressed adolescents.

These data suggest that mid-adolescence is a time of particular vulnerability to the effects of social stress on mPFC function. This vulnerability persists in females into adulthood but disappears in males. Given the likely role of layer $\mathrm{V}$ pyramidal neurons in behavioral flexibility and working memory (Wang et al., 2008), decreased excitability and synaptic transmission in these neurons could contribute to impairment of executive functions. Indeed, previous studies have shown that stress in adolescence impairs working memory and strategy-shifting in males, but only when tested in adulthood (Novick et al., 2013, 2016; Snyder and Valentino, 2015). Given that immediate stress-induced changes are seen on a cellular level in adolescent males but cognitive impacts appear later, adolescent rats may engage different brain circuits to complete these tasks while mPFC is still developing. Alternatively, immediate stress-induced changes in neuronal physiology may alter developmental trajectory, resulting in later emergence of deficits.

\section{Sensitivity of the parvalbumin (PV)} system to stress

Research in mouse models of stressrelated disorders supports sex-specific vulnerability: exposure to subchronic variable stress increases anxiety- and depressive-like behaviors in female but not male mice (Hodes et al., 2015). Similar sex-specific findings were observed after exposure to 4 weeks of unpredictable chronic mild stress, whereby female, but not male, mice developed anxiety-like behaviors (Shepard et al., 2016; Shepard and Coutellier, 2018). Identifying the molecular mechanisms underlying this sex-specific vulnerability to stress is critical, as this information can improve the diagnosis and prevention of stress-related mood disorders.

Evidence suggest that resilience or vulnerability to stressinduced emotional dysregulation may be modulated by prefrontal neuronal activity (Vialou et al., 2014; Labonté et al., 2017). The mPFC contains a heterogeneous population of excitatory pyramidal and inhibitory GABAergic neurons. Prefrontal GABAergic interneurons are the primary regulators of pyramidal neurons' spiking activity and are highly sensitive to modulation by stress (Maguire, 2014; Fuchikami et al., 2015). Their dysregulation during and following chronic stress likely affects MPFC activity and thereby emotional behaviors. GABAergic interneurons in the cortex form distinct subpopulations of inhibitory neurons based on their firing properties and molecular characteristics. Studies in rodents provide evidence for a strong effect of stress on all types of inhibitory neurons in the PFC. For instance, chronic stress reduces expression of somatostatin (Banasr et al., 2017), and somatostatin-expressing GABAergic neurons have long been thought to be involved in depression (Fee et al., 2017). Others have shown that mPFC activity during chronic social stress, regulated by cholecystokinin-GABA neurons, mediates the effects of chronic social defeat stress on social avoidance and sucrose preference in male mice (e.g., Vialou, 2014). Finally, findings from the L.C. laboratory and others showed that chronic stress impacts prefrontal PV-GABA interneurons (McKlveen et al., 2016; Shepard et al., 2016; Shepard and Coutellier, 2018). Specifically, 4 weeks of exposure to unpredictable chronic mild stress increases levels of PV mRNA in the ventral mPFC of female but not male mice. Increases in PV mRNA were positively correlated with increased emotionality in females only (Shepard et al., 2016), and was also associated with reduced cFos expression in non-PV cells, indicative of reduced prefrontal activity. Moreover, chronic stress increased the number of PV neurons expressing cFos, reflecting hyperactivity of this specific interneuronal population even after cessation of chronic stress. Recently, using a chemogenetic approach, we further supported the idea of a causal relation- 


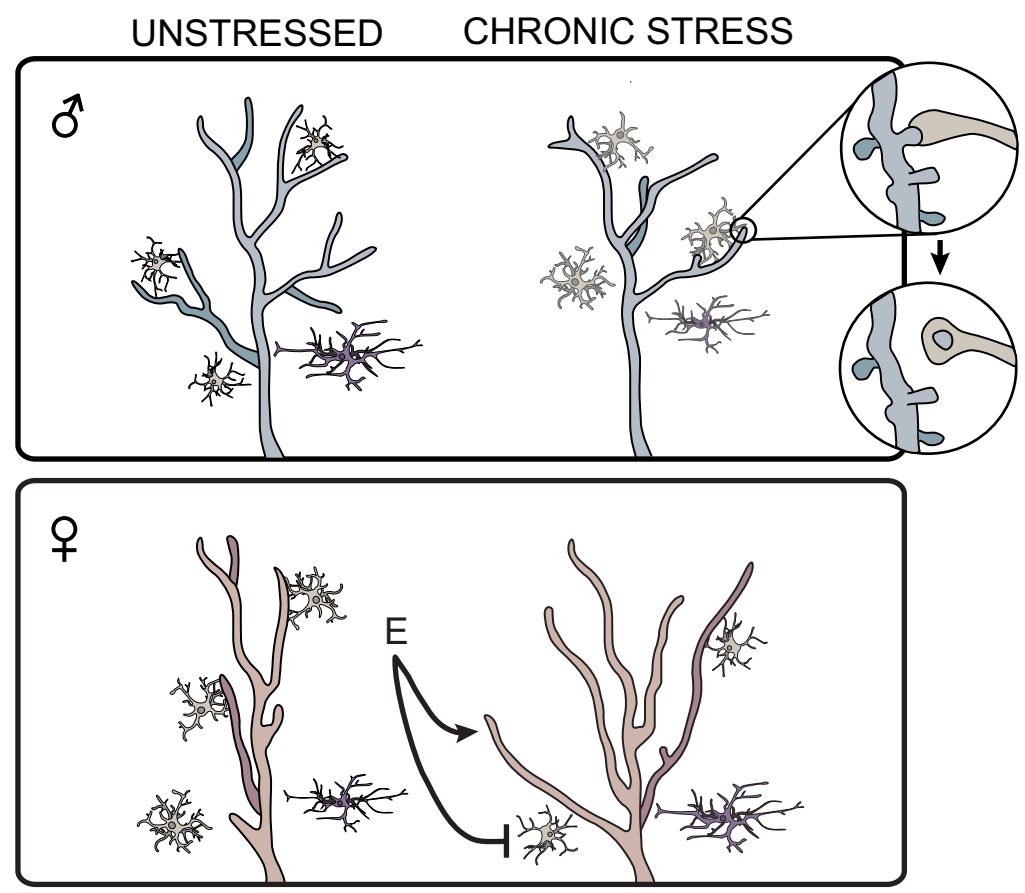

Figure 3. Hormonal contributions to sex-dependent stress effects on neuronal and glial morphology, and glia-neuron interaction in mPFC. Males (blue) exhibit increased apical dendritic complexity in pyramidal cells (red), increased astroglial ramification (purple), and reduced microglial activation (tan) compared with females. In males, chronic stress increases microglial activation, microglia-neuron interaction, and microglia-mediated synaptic pruning, decreases astroglial coverage, and reduces dendritic arborization. In females, chronic stress reduces microglial density and activation and increases astroglial coverage and dendritic complexity in mPFC. Estradiol $(\mathrm{E})$ is necessary for stress-induced microglial deactivation in females and the stress-linked dendritic remodeling reported by Garrett and Wellman (2009).

ship between dysregulation of prefrontal PV-expressing neurons and anxiety-like phenotype in female mice. Importantly, such a link between PV-expressing neurons and anxiety was not observed in males, suggesting a sex-specific pathway in the regulation of anxiety-like behaviors (L.C. et al., unpublished data). These novel findings showing changes in PV-expressing cells in the PFC after chronic stress are very important for our understanding of prefrontal activity changes in stress-related disorders. $\mathrm{PV}$-expressing interneurons form synapses onto the cell body and the axon initial segment of pyramidal cells. They are thus well positioned to provide strong inhibition of excitatory cells, much more so than, for instance, somatostatin-expressing neurons that regulate integration of dendritic input on pyramidal cells. Even small changes in the functioning of PV-expressing neurons might have important consequences for overall circuit activity.

Although cholecystokinin- and somatostatin-expressing neurons likely also regulate emotional behaviors (Freund, 2003; Sibille, 2017), our findings (Shepard et al., 2016; Shepard and Coutellier, 2018) suggest an important contribution of prefrontal PV-expressing neurons to sex-specific vulnerabilities to stress-induced emotional dysregulation. While many studies support the idea that different subpopulations of GABAergic neurons are sensitive to stress, electrophysiological studies indicating that hippocampal PV-expressing neurons are more vulnerable to the effects of stress than cholecystokinin-expressing cells ( $\mathrm{Hu}$ et al., 2010). Such findings support the idea that increased plasticity of the prefrontal PV-expressing neurons in response to chronic stress might heighten vulnerability to emotional dysregulation, which could contribute to the increased risk for anxiety and depressive disorders in females. Elucidating the molecular mechanisms for this sex-specific neuronal sensitiv- ity to stress could identify sex-specific targets for treatment for stress-sensitive disorders.

\section{Stress effects on glia}

Recent findings suggest glial contributions to stress-linked mood disorders, including depression (Miguel-Hidalgo et al., 2000; Holmes et al., 2018). For instance, microglial morphological activation and astroglial atrophy are observed in the $\mathrm{mPFC}$ in postmortem tissue from depressed patients (Miguel-Hidalgo et al., 2000; Torres-Platas et al., 2014), and markers of heightened neuroimmune activity in anterior cingulate cortex correlate with depressive symptom severity (Setiawan et al., 2015). Consistent with these data, preclinical models of depression demonstrate stress-induced alterations in microglia (Tynan et al., 2013), astrocytes (Banasr and Duman, 2008), and inflammatory priming (Frank et al., 2007) in numerous corticolimbic brain regions. Upon sensing a perturbation in the microenvironment, microglial processes thicken and reorient toward neuronal and astroglial signals (Ransohoff and Perry, 2009). Activated microglia can modulate neurotransmission, prune synapses and dendritic elements (Paolicelli et al., 2011), stimulate dendritic spine outgrowth (Weinhard et al., 2018), and potentially reshape dendritic architecture (Rappert et al., 2004; Salter and Beggs, 2014). Likewise, astrocytes are crucial in maintaining synaptic plasticity and function, including glutamatergic neurotransmission, regulate the neuroimmune milieu (Rossi, 2015), and likely contribute to depressive-like behaviors (Banasr and Duman, 2008).

In males, stress induces microglial morphological remodeling and inflammatory factor expression in mPFC (Hinwood et al., 2013), which contribute to stress-induced deficits in mPFC function (Hinwood et al., 2012; Kreisel et al., 2014; Wohleb et al., 2018). Chronic stress also reduces astroglial complexity and communication in $\mathrm{mPFC}$, and astroglial atrophy in $\mathrm{mPFC}$, produced by an astrocyte-specific toxin, is sufficient to induce a depressivelike phenotype (Banasr and Duman, 2008). Thus, glia may contribute to stress-induced alterations in synaptic function and behavior.

There are sex differences in microglial morphology in numerous stress-sensitive brain regions (e.g., Schwarz et al., 2012), including mPFC (Bollinger et al., 2016). However, few researchers have addressed sex-dependent stress effects on glia. In an initial report, acute restraint stress increased microglial morphological activation state in MPFC in males but decreased activation state in females. Microglial morphology returned to baseline following $10 \mathrm{~d}$ of daily restraint in males, whereas microglial deactivation persisted in females (Bollinger et al., 2016). These findings demonstrate sex-specific temporal patterns of stress-induced microglial remodeling in mPFC. Additional studies report sexdependent stress effects on microglial morphology (Bollinger et al., 2017) and inflammatory priming (Fonken et al., 2018) in other corticolimbic structures that interact extensively with mPFC (e.g., orbitofrontal cortex, hippocampus). 
Recent unpublished data (J.L.B. and C.L.W.) also suggest sex differences in, and sex-dependent stress effects on, morphology of astrocytes in mPFC. Males exhibit heightened astroglial coverage compared with females. Moreover, chronic stress induces atrophy of astrocytes in mPFC in males (Tynan et al., 2013) but may produce astroglial hypertrophy in females (J.L.B. and C.L.W., unpublished data).

Astrocytes and microglia can express estrogen and androgen receptors (Azcoitia et al., 1999; Sierra et al., 2008; Johnson et al., 2012). Therefore, gonadal hormones could contribute to sex differences in glial biology. Indeed, preliminary data suggest that ovariectomy prevents chronic stress-induced microglial deactivation in mPFC, and estradiol replacement may restore

These sex-, stress-, and hormone-dependent alterations in neuroimmune and glial activation could influence corticolimbic structure and functioning (Fig. 3). For instance, divergent microglial and astroglial patterns align with sex differences in dendritic morphology (Garrett and Wellman, 2009b; Shansky et al., 2010): unstressed females have reduced apical dendritic arbors on mPFC pyramidal neurons relative to males, which could be due to increased pruning of spines and branches by the moreactivated microglia in females. Similarly, the stress-induced decreases in microglial activity could either permit the dendritic growth in mPFC of stressed females that has been reported (Garrett and Wellman, 2009) or underlie the maintenance of normal dendritic lengths in stressed females reported previously (Moench and Wellman, 2017). Conversely, the stress-induced dendritic retraction seen in males could be driven by their increased microglial activity (Fig. 3). Supporting this hypothesis, stress induces microglia-neuron interaction and synaptic pruning in $\mathrm{mPFC}$ in males, but not females, and pharmacological inactivation of microglia during stress prevents stress-induced reductions in spine density in males (Wohleb et al., 2018). Moreover, reports demonstrate opposite molecular signatures in men and women with depression, which parallel patterns of stressinduced glial and neuronal remodeling in preclinical work. This includes heightened microglia-associated and reduced synapse-associated gene expression in PFC in postmortem tissue from depressed males, and reduced microglia-associated and heightened synapse-associated gene expression in depressed females (Seney et al., 2018). Together, these findings suggest a role for sex-dependent glial mechanisms in stresslinked psychopathology.

\section{Lasting effects of chronic stress on corticolimbic structure and function}

Immediately following chronic restraint stress (CRS), male rats have dendritic retraction in the prelimbic (PL) subregion of mPFC and deficits in behaviors mediated by mPFC (Holmes and Wellman, 2009). Chronically stressed female rats typically do not show deficits in many of these same behaviors (Wei et al., 2014; Snyder et al., 2015), and have either no dendritic remodeling (Moench and Wellman, 2017) or dendritic outgrowth (Garrett and Wellman, 2009) in mPFC. The discrepancy in chronic stressinduced dendritic remodeling in $\mathrm{mPFC}$ in females in these two studies is likely due to stressor duration ( $10 \mathrm{~d}$ vs $7 \mathrm{~d}$ ) and/or the specific subregions analyzed (PL only vs PL and anterior cingulate cortex, respectively). Regardless, what is consistent across these studies is that chronic stress results in sex-specific dendritic remodeling and behavioral changes in rats. A similar pattern of results is found in dorsal hippocampus, such that CRS induces dendritic retraction and behavioral deficits in males but not females (Bowman et al., 2003; Conrad et al., 2003, 2004; McLaughlin et al., 2009). Together, these studies suggest that male rats may be more susceptible to the detrimental effects of prolonged stress exposure, whereas female rats appear to have some level of resiliency. This is paradoxical given women's increased susceptibility to several stress-linked psychopathologies. Investigation of the long-term effects of CRS may resolve this apparent paradox.

CRS-induced dendritic atrophy in CA3 of males is ameliorated following a 10 day rest period (Conrad et al., 1999), and behavioral deficits are reversed following a poststress rest period (Sousa et al., 2000). Dendritic retraction in PL of CRS male rats is also ameliorated following a 21 day rest period (Radley et al., 2005). However, this process occurs more rapidly and is quite dynamic. CRS-induced dendritic retraction is absent following a 10 day rest period; and, surprisingly, dendritic outgrowth beyond unstressed lengths is present after a 7 day rest period, indicating that "recovery" from stress may not involve a simple return to baseline. Instead, changes during the poststress period likely involve the recruitment of important neuroadaptive mechanisms, resulting in a new functional state distinct from both stress-naive and chronically stressed rats, as was highlighted in a recent review by Ortiz and Conrad (2018). In contrast to the dynamic pattern of dendritic reorganization in male rats during the post-stress rest period, females show minimal dendritic remodeling in $\mathrm{mPFC}$ during this poststress period (Fig. 4) (Moench and Wellman, 2017), suggesting that in the days following chronic stress PL of females may be less plastic than that of males.

If so, then subsequent stress during the post-CRS rest period, a second hit, may have novel effects on the function of stresssensitive brain regions, and these effects may be sex-dependent. Indeed, in male rats exposed to chronic variable stress, exposure to a novel acute stressor produces reductions in cFos mRNA expression in several brain regions (Ostrander et al., 2006, 2009). Similarly, in the paraventricular nucleus of the hypothalamus, $\mathrm{mPFC}$, and hippocampal CA1 and dentate gyrus, cFos expression assessed via immunohistochemistry is reduced in male rats exposed to a novel acute stressor the day following CRS, and partially ameliorated when acute stress occurs after a 7 day rest period (K.M.M. et al., manuscript under review). In contrast, in females, prior CRS does not blunt novel acute stress-induced 
neuronal activation, regardless of whether acute stress occurs before or after a recovery period. Notably, CRS followed by a rest period increased neuronal activation in the paraventricular nucleus of the hypothalamus and BLA following acute stress (K.M.M. et al., manuscript under review). These findings suggest that males may show initial buffering after CRS, followed by reemergence of a more typical acute stress response, whereas CRS females may have an exaggerated neuroendocrine response to subsequent stressors.

This raises the possibility that CRS-induced changes in male rats may protect against subsequent stressors, whereas female rats may be more susceptible to two-hit stress. Preliminary data support this hypothesis, demonstrating that, despite immediate chronic stress-induced deficits in behavioral flexibility (Nikiforuk and Popik, 2014), reflected in performance on the attentional set-shifting task (Birrell and Brown, 2000), male rats do not appear to have deficits after two-hit stress (K.M.M. and C.L.W., unpublished data). Conversely, females do not appear to have deficits in behavioral flexibility immediately after chronic stress, but exposure to a novel acute stressor after a recovery period may induce deficits in behavioral flexibility (K.M.M. and C.L.W., unpublished data). Understanding this potential female-biased vulnerability to multiple stressors may begin to elucidate mechanisms underlying increased risk for stress-linked psychological disorders in women.

\section{Discussion}

Together, these studies illustrate several important emerging themes in sex-dependent stress effects on the neural circuitry underlying emotion, motivation, and cognition. First, sex differences in the effects of stress are nuanced. Just as sex differences in risk for psychopathology include both male-biased and femalebiased disorders, sex differences in stress effects include examples of male vulnerability (e.g., CRF's effects on cholinergic processing) as well as female vulnerability (e.g., CRF's effects on noradrenergic processing). Second, sex-dependent effects of stress may be nonlinear, as in the dynamic dendritic remodeling seen in mPFC of males subsequent to CRS, and the late emergence of deleterious effects of CRS in mPFC of females. Third, sex differences in stress effects can be quite variable, depending on the animal model used (e.g., unpredictable chronic mild stress in mice vs CRS in rats), the timing of stress and testing (e.g., different patterns of persistence of the effects of adolescent social stress on physiology of mPFC in males vs females), and brain regions examined (e.g., sex differences in glucocorticoid modulation of activity in CeL but not CeM). Finally, given the extensive interactions among the brain regions highlighted in this brief review, studies of mechanisms underlying sex differences will need to take into account not just neuronal mechanisms, but also circuitlevel interactions, as well as potential contributions of nonneuronal pathways involving neuron-glia interactions. While such mechanistic studies are still in their infancy, elucidating the mechanisms contributing to sex-dependent effects of stress on corticolimbic physiology can reveal the basis of sex differences in psychopathology, and inform the development of better treatments for these disorders in men and women.

\section{References}

Arnsten AF, Li BM (2005) Neurobiology of executive functions: catecholamine influences on prefrontal cortical functions. Biol Psychiatry 57: 1377-1384. CrossRef Medline

Azcoitia I, Sierra A, Miguel Garcia-Segura LM (1999) Localization of estrogen receptor $\beta$-immunoreactivity in astrocytes of the adult rat brain. Glia 26:260-267. CrossRef Medline
Banasr M, Duman RS (2008) Glial loss in the prefrontal cortex is sufficient to induce depressive-like behaviors. Biol Psychiatry 64:863-870. CrossRef Medline

Banasr M, Nikolova Y, Misquitta K, Rocco B, Prevot T, Knodt A, Hariri A, Voineskos A, Ellegood J, Lerch JP, Sibille E (2017) Behavioral and brain network adaptations to chronic stress, a translational study. Biol Psychiatry 81:S64-S64. CrossRef

Bangasser DA, Wicks B (2017) Sex-specific mechanisms for responding to stress. J Neurosci Res 95:75-82. CrossRef Medline

Bangasser DA, Curtis A, Reyes BA, Bethea TT, Parastatidis I, Ischiropoulos H, Van Bockstaele EJ, Valentino RJ (2010) Sex differences in corticotropinreleasing factor receptor signaling and trafficking: potential role in female vulnerability to stress-related psychopathology. Mol Psychiatry 15:896904. CrossRef Medline

Bangasser DA, Reyes BA, Piel D, Garachh V, Zhang XY, Plona ZM, Van Bockstaele EJ, Beck SG, Valentino RJ (2013) Increased vulnerability of the brain norepinephrine system of females to corticotropin-releasing factor overexpression. Mol Psychiatry 18:166-173. CrossRef Medline

Bangasser DA, Wiersielis KW, Wicks B, Salvatore M, Cohen S, Ceretti A, Bergmann J, Duncan N, Lefebo H (2016) ACNP 55th annual meeting: poster session II, December 6, 2016. Neuropsychopharmacology 41:S289. CrossRef

Bangasser DA, Eck SR, Telenson AM, Salvatore M (2018) Sex differences in stress regulation of arousal and cognition. Physiol Behav 187:42-50. CrossRef Medline

Bennett MR (2011) The prefrontal-limbic network in depression: a core pathology of synapse regression. Prog Neurobiol 93:457-467. CrossRef Medline

Bertholomey ML, Torregrossa MM (2017) Gonadal hormones affect alcohol drinking, but not cue + yohimbine-induced alcohol seeking, in male and female rats. Physiol Behav. Advance online publication. Retrieved October 26, 2017. doi: 10.1016/j.physbeh.2017.10.025. CrossRef Medline

Bertholomey ML, Nagarajan V, Torregrossa MM (2016) Sex differences in reinstatement of alcohol seeking in response to cues and yohimbine in rats with and without a history of adolescent corticosterone exposure. Psychopharmacology (Berl) 233:2277-2287. CrossRef Medline

Birrell JM, Brown VJ (2000) Medial frontal cortex mediates perceptual attentional set shifting in the rat. J Neurosci 20:4320-4324. CrossRef Medline

Blaine SK, Sinha R (2017) Alcohol, stress, and glucocorticoids: from risk to dependence and relapse in alcohol use disorders. Neuropharmacology 122:136-147. CrossRef Medline

Bollinger JL, Bergeon Burns CM, Wellman CL (2016) Differential effects of stress on microglial cell activation in male and female medial prefrontal cortex. Brain Behav Immun 52:88-97. CrossRef Medline

Bollinger JL, Collins KE, Patel R, Wellman CL (2017) Behavioral stress alters corticolimbic microglia in a sex- and brain region-specific manner. PLoS One 12:e0187631. CrossRef Medline

Bowman RE, Beck KD, Luine VN (2003) Chronic stress effects on memory: sex differences in performance and monoaminergic activity. Horm Behav 43:48-59. CrossRef Medline

Bremner JD, Licinio J, Darnell A, Krystal JH, Owens MJ, Southwick SM, Nemeroff CB, Charney DS (1997) Elevated CSF corticotropin-releasing factor concentrations in posttraumatic stress disorder. Am J Psychiatry 154:624-629. CrossRef Medline

Breslau N (2009) The epidemiology of trauma, PTSD, and other posttrauma disorders. Trauma Violence Abuse 10:198-210. CrossRef Medline

Bryce CA, Floresco SB (2016) Perturbations in effort-related decisionmaking driven by acute stress and corticotropin-releasing factor. Neuropsychopharmacology 41:2147-2159. CrossRef Medline

Casey A (1960) The effect of stress on the consumption of alcohol and reserpine. Q J Stud Alcohol 21:208-216. Medline

Chester JA, de Paula Barrenha G, DeMaria A, Finegan A (2006) Different effects of stress on alcohol drinking behaviour in male and female mice selectively bred for high alcohol preference. Alcohol Alcohol 41:44-53. CrossRef Medline

Ciccocioppo R, de Guglielmo G, Hansson AC, Ubaldi M, Kallupi M, Cruz MT, Oleata CS, Heilig M, Roberto M (2014) Restraint stress alters nociceptin/orphanin FQ and CRF systems in the rat central amygdala: significance for anxiety-like behaviors. J Neurosci 34:363-372. CrossRef Medline 
Cole RD, Kawasumi Y, Parikh V, Bangasser DA (2016) Corticotropin releasing factor impairs sustained attention in male and female rats. Behav Brain Res 296:30-34. CrossRef Medline

Conrad CD, LeDoux JE, Magariños AM, McEwen BS (1999) Repeated restraint stress facilitates fear conditioning independently of causing hippocampal CA3 dendritic atrophy. Behav Neurosci 113:902-913. CrossRef Medline

Conrad CD, Grote KA, Hobbs RJ, Ferayorni A (2003) Sex differences in spatial and non-spatial Y-maze performance after chronic stress. Neurobiol Learn Mem 79:32-40. CrossRef Medline

Conrad CD, Jackson JL, Wieczorek L, Baran SE, Harman JS, Wright RL, Korol DL (2004) Acute stress impairs spatial memory in male but not female rats: influence of estrous cycle. Pharmacol Biochem Behav 78:569-579. CrossRef Medline

Cozzoli DK, Tanchuck-Nipper MA, Kaufman MN, Horowitz CB, Finn DA (2014) Environmental stressors influence limited-access ethanol consumption by C57BL/6J mice in a sex-dependent manner. Alcohol 48:741754. CrossRef Medline

Curtis AL, Bethea T, Valentino RJ (2006) Sexually dimorphic responses of the brain norepinephrine system to stress and corticotropin-releasing factor. Neuropsychopharmacology 31:544-554. CrossRef Medline

de Graaf R, Bijl RV, Smith F, Vollebergh WAM, Spijker J (2002) Risk factors for 12-month comorbidity of mood, anxiety, and substance use disorders: Findings from the netherlands mental health survey and incidence study. Am J Psychiatr 159:620-629. CrossRef Medline

Farrell MR, Sengelaub DR, Wellman CL (2013) Sex differences and chronic stress effects on the neural circuitry underlying fear conditioning and extinction. Physiol Behav 122:208-215. CrossRef Medline

Fee C, Banasr M, Sibille E (2017) Somatostatin-positive gamma-aminobutyric acid interneuron deficits in depression: cortical microcircuit and therapeutic perspectives. Biol Psychiatry 82:549-559. CrossRef Medline

Fonken LK, Frank MG, Gaudet AD, D’Angelo HM, Daut RA, Hampson EC, Ayala MT, Watkins LR, Maier SF (2018) Neuroinflammatory priming to stress is differentially regulated in male and female rats. Brain Behav Immun 70:257-267. CrossRef Medline

Frank MG, Baratta MV, Sprunger DB, Watkins LR, Maier SF (2007) Microglia serve as a neuroimmune substrate for stress-induced potentiation of CNS pro-inflammatory cytokine responses. Brain Behav Immun 21:4759. CrossRef Medline

Freund TF (2003) Interneuron diversity series: rhythm and mood in perisomatic inhibition. Trends Neurosci 26:489-495. CrossRef Medline

Fuchikami M, Thomas A, Liu R, Wohleb ES, Land BB, DiLeone RJ, Aghajanian GK, Duman RS (2015) Optogenetic stimulation of infralimbic PFC reproduces ketamine's rapid and sustained antidepressant actions. Proc Natl Acad Sci U S A 112:8106-8111. CrossRef Medline

Garrett JE, Wellman CL (2009) Chronic stress effects on dendritic morphology in medial prefrontal cortex: sex differences and estrogen dependence. Neuroscience 162:195-207. CrossRef Medline

Girotti M, Adler SM, Bulin SE, Fucich EA, Paredes D, Morilak DA (2018) Prefrontal cortex executive processes affected by stress in health and disease. Prog Neuropsychopharmacol Biol Psychiatry 85:161-179. CrossRef Medline

Goldman-Rakic PS (1996) The prefrontal landscape: implications of functional architecture for understanding human mentation and the central executive. Philos Trans R Soc Lond B Biol Sci 351:1445-1453. CrossRef Medline

Grammatopoulos DK, Randeva HS, Levine MA, Kanellopoulou KA, Hillhouse EW (2001) Rat cerebral cortex corticotropin-releasing hormone receptors: evidence for receptor coupling to multiple g-proteins. J Neurochem 76:509-519. CrossRef Medline

Hartwell EE, Ray LA (2013) Sex moderates stress reactivity in heavy drinkers. Addict Behav 38:2643-2646. CrossRef Medline

Heffner JL, Blom TJ, Anthenelli RM (2011) Gender differences in trauma history and symptoms as predictors of relapse to alcohol and drug use. Am J Addict 20:307-311. CrossRef Medline

Heuser I, Bissette G, Dettling M, Schweiger U, Gotthardt U, Schmider J, Lammers CH, Nemeroff CB, Holsboer F (1998) CSF concentrations of corticotropin-releasing hormone, vasopressin, and somatostatin in depressed patients and healthy controls: response to amitriptyline treatment. Depress Anxiety 8:71-79. CrossRef Medline

Hinwood M, Morandini J, Day TA, Walker FR (2012) Evidence that micro- glia mediate the neurobiological effects of chronic psychological stress on the medial prefrontal cortex. Cereb Cortex 22:1442-1454. CrossRef Medline

Hinwood M, Tynan RJ, Charnley JL, Beynon SB, Day TA, Walker FR (2013) Chronic stress induced remodeling of the prefrontal cortex: structural re-organization of microglia and the inhibitory effect of minocycline. Cereb Cortex 23:1784-1797. CrossRef Medline

Hirvikoski T, Lindholm T, Nordenström A, Nordström AL, Lajic S (2009) High self-perceived stress and many stressors, but normal diurnal cortisol rhythm, in adults with ADHD (attention-deficit/hyperactivity disorder). Horm Behav 55:418-424. CrossRef Medline

Hodes GE, Pfau ML, Purushothaman I, Francisca Ahn H, Golden SA, Christoffel DL, Magida J, Brancato A, Takahashi A, Flanigan ME, Ménard C, Aleyasin H, Koo JW, Lorsch ZS, Feng J, Heshmati M, Wang M, Turecki G, Neve R, Zhang B, et al. (2015) Sex differences in nucleus accumbens transcriptome profiles associated with susceptibility versus resilience to subchronic variable stress. J Neurosci 35:16362-16376. CrossRef

Holmes A, Wellman CL (2009) Stress-induced prefrontal reorganization and executive dysfunction in rodents. Neurosci Biobehav Rev 33:773783. CrossRef Medline

Holmes SE, Hinz R, Conen S, Gregory CJ, Matthews JC, Anton-Rodriguez JM, Gerhard A, Talbot PS (2018) Elevated translocator protein in anterior cingulate in major depression and a role for inflammation in suicidal thinking: a positron emission tomography study. Biol Psychiatry 83:6169. CrossRef Medline

Hu W, Zhang M, Czéh B, Flügge G, Zhang W (2010) Stress impairs GABAergic network function in the hippocampus by activating nongenomic glucocorticoid receptors and affecting the integrity of the parvalbuminexpressing neuronal network. Neuropsychopharmacology 35:1693-1707. CrossRef Medline

Hupalo S, Berridge CW (2016) Working memory impairing actions of corticotropin-releasing factor (CRF) neurotransmission in the prefrontal cortex. Neuropsychopharmacology 41:2733-2740. CrossRef Medline

Jaferi A, Bhatnagar S (2007) Corticotropin-releasing hormone receptors in the medial prefrontal cortex regulate hypothalamic-pituitary-adrenal activity and anxiety-related behavior regardless of prior stress experience. Brain Res 1186:212-223. CrossRef Medline

Janak PH, Tye KM (2015) From circuits to behaviour in the amygdala. Nature 517:284-292. CrossRef Medline

Jedema HP, Grace AA (2004) Corticotropin-releasing hormone directly activates noradrenergic neurons of the locus ceruleus recorded in vitro. J Neurosci 24:9703-9713. CrossRef Medline

Johnson RT, Schneider A, DonCarlos LL, Breedlove SM, Jordan CL (2012) Astrocytes in the rat medial amygdala are responsive to adult androgens. J Comp Neurol 520:2531-2544. CrossRef Medline

Kessler RC, Petukhova M, Sampson NA, Zaslavsky AM, Wittchen HU (2012) Twelve-month and lifetime prevalence and lifetime morbid risk of anxiety and mood disorders in the united states. Int J Methods Psychiatr Res 21:169-184. CrossRef Medline

Kirson D, Oleata CS, Parsons LH, Ciccocioppo R, Roberto M (2018) $\mathrm{CB}_{1}$ and ethanol effects on glutamatergic transmission in the central amygdala of male and female MSP and Wistar rats. Addict Biol 23:676-688. CrossRef Medline

Koob GF (2015) The dark side of emotion: the addiction perspective. Eur J Pharmacol 753:73-87. CrossRef Medline

Koss WA, Hristov AD, Juraska JM (2010) Dendritic changes from preadolescence to adulthood in the medial prefrontal cortex of the male and female rat. In: Program No. 640.04. 2010 Neuroscience Meeting Planner. San Diego: Society for Neuroscience.

Koss WA, Belden CE, Hristov AD, Juraska JM (2014) Dendritic remodeling in the adolescent medial prefrontal cortex and the basolateral amygdala of male and female rats. Synapse 68:61-72. CrossRef Medline

Kreisel T, Frank MG, Licht T, Reshef R, Ben-Menachem-Zidon O, Baratta MV, Maier SF, Yirmiya R (2014) Dynamic microglial alterations underlie stress-induced depressive-like behavior and suppressed neurogenesis. Mol Psychiatry 19:699-709. CrossRef Medline

Labonté B, Engmann O, Purushothaman I, Menard C, Wang J, Tan C, Scarpa JR, Moy G, Loh YE, Cahill M, Lorsch ZS, Hamilton PJ, Calipari ES, Hodes GE, Issler O, Kronman H, Pfau M, Obradovic AL, Dong Y, Neve RL, et al. (2017) Sex-specific transcriptional signatures in human depression. Nat Med 23:1102-1111. CrossRef Medline

Lenroot RK, Giedd JN (2006) Brain development in children and adoles- 
cents: insights from anatomical magnetic resonance imaging. Neurosci Biobehav Rev 30:718-729. CrossRef Medline

Lewis DA (1997) Development of the prefrontal cortex during adolescence: insights into vulnerable neural circuits in schizophrenia. Neuropsychopharmacology 16:385-398. CrossRef Medline

Logrip ML, Zorrilla EP (2012) Stress history increases alcohol intake in relapse: relation to phosphodiesterase 10a. Addict Biol 17:920-933. CrossRef Medline

Logrip ML, Vendruscolo LF, Schlosburg JE, Koob GF, Zorrilla EP (2014) Phosphodiesterase 10a regulates alcohol and saccharin self-administration in rats. Neuropsychopharmacology 39:1722-1731. CrossRef Medline

Logrip ML, Oleata C, Roberto M (2017) Sex differences in responses of the basolateral-central amygdala circuit to alcohol, corticosterone and their interaction. Neuropharmacology 114:123-134. CrossRef Medline

Lynch WJ, Kushner MG, Rawleigh JM, Fiszdon J, Carroll ME (1999) The effects of restraint stress on voluntary ethanol consumption in rats. Exp Clin Psychopharmacol 7:318-323. CrossRef Medline

Maguire J (2014) Stress-induced plasticity of GABAergic inhibition. Front Cell Neurosci 8:1-8. CrossRef Medline

Maren S, Holmes A (2016) Stress and fear extinction. Neuropsychopharmacol Rev 41:58-79. CrossRef Medline

McKlveen JM, Morano RL, Fitzgerald M, Zoubovsky S, Cassella SN, Scheimann JR, Ghosal S, Mahbod P, Packard BA, Myers B, Baccei ML, Herman JP (2016) Chronic stress increases prefrontal inhibition: a mechanism for stress-induced prefrontal dysfunction. Biol Psychiatry 80 : 754-764. CrossRef Medline

McLaughlin KJ, Baran SE, Conrad CD (2009) Chronic stress- and sexspecific neuromorphological and functional changes in limbic structures. Mol Neurobiol 40:166-182. CrossRef Medline

Mendrek A, Mancini-Marie A (2016) Sex/gender differences in the brain and cognition in schizophrenia. Neurosci Biobehav Rev 67:57-78. CrossRef Medline

Miguel-Hidalgo JJ, Baucom C, Dilley G, Overholser JC, Meltzer HY, Stockmeier CA, Rajkowska G (2000) Glial fibrillary acidic protein immunoreactivity in the prefrontal cortex distinguishes younger from older adults in major depressive disorder. Biol Psychiatry 48:861-873. CrossRef Medline

Moench KM, Wellman CL (2015) Stress-induced alterations in prefrontal dendritic spines: implications for post-traumatic stress disorder. Neurosci Lett 601:41-45. CrossRef Medline

Moench KM, Wellman CL (2017) Differential dendritic remodeling in prelimbic cortex of male and female rats during recovery from chronic stress. Neuroscience 357:145-159. CrossRef Medline

Negrón-Oyarzo I, Aboitiz F, Fuentealba P (2016) Impaired functional connectivity in the prefrontal cortex: a mechanism for chronic stress-induced neuropsychiatric disorders. Neural Plast 2016:7539065. CrossRef Medline

Newman SC, Bland RC (1994) Life events and the 1-year prevalence of major depressive episode, generalized anxiety disorder, and panic disorder in a community sample. Compr Psychiatry 35:76-82. CrossRef Medline

Nikiforuk A, Popik P (2014) Ketamine prevents stress-induced cognitive inflexibility in rats. Psychoneuroendocrinology 40:119-122. CrossRef Medline

Novick AM, Miiller LC, Forster GL, Watt MJ (2013) Adolescent social defeat decreases spatial working memory performance in adulthood. Behav Brain Funct 9:39. CrossRef Medline

Novick AM, Mears M, Forster GL, Lei Y, Tejani-Butt SM, Watt MJ (2016) Adolescent social defeat alters $\mathrm{N}$-methyl-D-aspartic acid receptor expression and impairs fear learning in adulthood. Behav Brain Res 304:51-59. CrossRef Medline

Ortiz JB, Conrad CD (2018) The impact from the aftermath of chronic stress on hippocampal structure and function: Is there a recovery? Frontiers in Neuroendocrinology 49:114-123. CrossRef Medline

Ostrander MM, Ulrich-Lai YM, Choi DC, Richtand NM, Herman JP (2006) Hypoactivity of the hypothalamo-pituitary-adrenocortical axis during recovery from chronic variable stress. Endocrinology 147:2008-2017. CrossRef Medline

Ostrander MM, Ulrich-Lai YM, Choi DC, Flak JN, Richtand NM, Herman JP (2009) Chronic stress produces enduring decreases in novel stressevoked c-fos mRNA expression in discrete brain regions of the rat. Stress 12:469-477. CrossRef Medline

Paolicelli RC, Bolasco G, Pagani F, Maggi L, Scianni M, Panzanelli P, Gi- ustetto M, Ferreira TA, Guiducci E, Dumas L, Ragozzino D, Gross CT (2011) Synaptic pruning by microglia is necessary for normal brain development. Science 333:1456-1458. CrossRef Medline

Radley JJ, Rocher AB, Janssen WG, Hof PR, McEwen BS, Morrison JH (2005) Reversibility of apical dendritic retraction in the rat medial prefrontal cortex following repeated stress. Exp Neurol 196:199-203. CrossRef Medline

Ramtekkar UP, Reiersen AM, Todorov AA, Todd RD (2010) Sex and age differences in attention-deficit/hyperactivity disorder symptoms and diagnoses: Implications for DSM-V and ICD-11. J Am Acad Child Adolesc Psychiatry 49:217-228.e1-3. Medline

Ransohoff RM, Perry VH (2009) Microglial physiology: unique stimuli, specialized responses. In: Annual review of immunology, pp 119-145. Palo Alto, CA: Annual Review.

Rappert A, Bechmann I, Pivneva T, Mahlo J, Biber K, Nolte C, Kovac AD, Gerard C, Boddeke HW, Nitsch R, Kettenmann H (2004) CXCR3dependent microglial recruitment is essential for dendrite loss after brain lesion. J Neurosci 24:8500-8509. CrossRef Medline

Roberto M, Madamba SG, Moore SD, Tallent MK, Siggins GR (2003) Ethanol increases GABAergic transmission at both pre- and postsynaptic sites in rat central amygdala neurons. Proc Natl Acad Sci U S A 100:20532058. CrossRef Medline

Roberto M, Madamba SG, Stouffer DG, Parsons LH, Siggins GR (2004a) Increased GABA release in the central amygdala of ethanol-dependent rats. J Neurosci 24:10159-10166. CrossRef Medline

Roberto M, Schweitzer P, Madamba SG, Stouffer DG, Parsons LH, Siggins GR (2004b) Acute and chronic ethanol alter glutamatergic transmission in rat central amygdala: an in vitro and in vivo analysis. J Neurosci 24:15941603. CrossRef Medline

Rossi D (2015) Astrocyte physiopathology: at the crossroads of intercellular networking, inflammation and cell death. Prog Neurobiol 130:86-120. CrossRef Medline

Salter MW, Beggs S (2014) Sublime microglia: expanding roles for the guardians of the CNS. Cell 58:15-25. CrossRef Medline

Sarter M, Givens B, Bruno JP (2001) The cognitive neuroscience of sustained attention: where top-down meets bottom-up. Brain Res Rev 35: 146-160. CrossRef Medline

Schoevers RA, Beekman ATF, Deeg DJH, Jonker C, van Tilburg W (2003) Comorbidity and risk-pattems of depression, generalised anxiety disorder and mixed anxiety-depression in later life: Results from the amstel study. Int J Geriatr Psych 18:994-1001. CrossRef Medline

Schwarz JM, Sholar PW, Bilbo SD (2012) Sex differences in microglial colonization of the developing rat brain. J Neurochem 120:948-963. CrossRef Medline

Seney ML, Huo Z, Cahill K, French L, Puralewski R, Zhang J, Logan RW, Tseng G, Lewis DA, Sibille E (2018) Opposite molecular signatures of depression in men and women. Biol Psychiatry 84:18-27. CrossRef Medline

Setiawan E, Wilson AA, Mizrahi R, Rusjan PM, Miler L, Rajkowska G, Suridjan I, Kennedy JL, Rekkas PV, Houle S, Meyer JH (2015) Role of translocator protein density, a marker of neuroinflammation, in the brain during major depressive episodes. JAMA Psychiatry 72:268-275. CrossRef Medline

Shansky RM, Hamo C, Hof PR, Lou W, McEwen BS, Morrison JH (2010) Estrogen promotes stress sensitivity in a prefrontal cortex-amygdala pathway. Cereb Cortex 20:2560-2567. CrossRef Medline

Shepard R, Coutellier L (2018) Changes in the prefrontal glutamatergic and parvalbumin systems of mice exposed to unpredictable chronic stress. Mol Neurobiol 55:2591-2602. CrossRef Medline

Shepard R, Page CE, Coutellier L (2016) Sensitivity of the prefrontal GABAergic system to chronic stress in male and female mice: relevance for sex differences in stress-related disorders. Neuroscience 332:1-12. CrossRef Medline

Sibille E (2017) Reduced somatostatin expression or somatostatin-positive gamma-aminobutyric acid neurons: a shared pathology across brain disorders. Biol Psychiatry 81:467-469. CrossRef Medline

Sierra A, Gottfried-Blackmore A, Milner TA, McEwen BS, Bulloch K (2008) Steroid hormone receptor expression and function in microglia. Glia 56: 659-674. CrossRef Medline

Simms JA, Haass-Koffler CL, Bito-Onon J, Li R, Bartlett SE (2012) Mifepristone in the central nucleus of the amygdala reduces yohimbine stress- 
induced reinstatement of ethanol-seeking. Neuropsychopharmacology 37:906-918. CrossRef Medline

Sinha R (2013) The clinical neurobiology of drug craving. Curr Opin Neurobiol 23:649-654. CrossRef Medline

Snyder KP, Valentino RJ (2015) Cognitive impact of social stress and coping strategy throughout development. Psychopharmacology (Berl) 232:185195. CrossRef Medline

Snyder K, Barry M, Plona Z, Ho A, Zhang XY, Valentino RJ (2015) The impact of social stress during adolescence or adulthood and coping strategy on cognitive function of female rats. Behav Brain Res 286:175-183. CrossRef Medline

Sousa N, Lukoyanov NV, Madeira MD, Almeida OF, Paula-Barbosa MM (2000) Reorganization of the morphology of hippocampal neurites and synapses after stress-induced damage correlates with behavioral improvement. Neuroscience 97:253-266. CrossRef Medline

Torres-Platas SG, Cruceanu C, Chen GG, Turecki G, Mechawar N (2014) Evidence for increased microglial priming and macrophage recruitment in the dorsal anterior cingulate white matter of depressed suicides. Brain Behav Immun 42:50-59. CrossRef Medline

Tynan RJ, Beynon SB, Hinwood M, Johnson SJ, Nilsson M, Woods JJ, Walker FR (2013) Chronic stress-induced disruption of the astrocyte network is driven by structural atrophy and not loss of astrocytes. Acta Neuropathol 126:75-91. CrossRef Medline

Urban KR, Valentino RJ (2017) Age- and sex-dependent impact of repeated social stress on intrinsic and synaptic excitability of the rat prefrontal cortex. Cereb Cortex 27:244-253. CrossRef Medline

Valentino RJ, Van Bockstaele EJ (2005) Functional interactions between stress neuromediators and the locus coeruleus-norepinephrine system. In: Techniques in the behavioral and neural sciences (Steckler T, Kalin NH, Reul JM, eds), pp 465-486. Amsterdam: Elsevier.

Vendruscolo LF, Barbier E, Schlosburg JE, Misra KK, Whitfield TW Jr, Logrip ML, Rivier C, Repunte-Canonigo V, Zorrilla EP, Sanna PP, Heilig M, Koob GF (2012) Corticosteroid-dependent plasticity mediates compulsive alcohol drinking in rats. J Neurosci 32:7563-7571. CrossRef Medline

Vendruscolo LF, Estey D, Goodell V, Macshane LG, Logrip ML, Schlosburg JE, McGinn MA, Zamora-Martinez ER, Belanoff JK, Hunt HJ, Sanna PP, George O, Koob GF, Edwards S, Mason BJ (2015) Glucocorticoid recep- tor antagonism decreases alcohol seeking in alcohol-dependent individuals. J Clin Invest 125:3193-3197. CrossRef Medline

Vialou V (2014) Delta fosb in the prefrontal cortex, susceptibility to social stress and antipsychotic treatment. Schizophr Res 153:S29-S29. CrossRef

Vialou V, Bagot RC, Cahill ME, Ferguson D, Robison AJ, Dietz DM, Fallon B, Mazei-Robison M, Ku SM, Harrigan E, Winstanley CA, Joshi T, Feng J, Berton O, Nestler EJ (2014) Prefrontal cortical circuit for depressionand anxiety-related behaviors mediated by cholecystokinin: role of $\delta$ fosb. J Neurosci 34:3878-3887. CrossRef Medline

Wang H, Stradtman GG 3rd, Wang XJ, Gao WJ (2008) A specialized NMDA receptor function in layer 5 recurrent microcircuitry of the adult rat prefrontal cortex. Proc Natl Acad Sci U S A 105:16791-16796. CrossRef Medline

Wei J, Yuen EY, Liu W, Li X, Zhong P, Karatsoreos IN, McEwen BS, Yan Z (2014) Estrogen protects against the detrimental effects of repeated stress on glutamatergic transmission and cognition. Mol Psychiatry 19:588598. CrossRef Medline

Weinhard L, di Bartolomei G, Bolasco G, Machado P, Schieber NL, Neniskyte U, Exiga M, Vadisiute A, Raggioli A, Schertel A, Schwab Y, Gross CT (2018) Microglia remodel synapses by presynaptic trogocytosis and spine head filopodia induction. Nat Commun 9:1228. CrossRef Medline

White A, Castle IJ, Chen CM, Shirley M, Roach D, Hingson R (2015) Converging patterns of alcohol use and related outcomes among females and males in the united states, 2002 to 2012. Alcohol Clin Exp Res 39:17121726. CrossRef Medline

Wille-Bille A, Ferreyra A, Sciangula M, Chiner F, Nizhnikov ME, Pautassi RM (2017) Restraint stress enhances alcohol intake in adolescent female rats but reduces alcohol intake in adolescent male and adult female rats. Behav Brain Res 332:269-279. CrossRef Medline

Wohleb ES, Terwilliger R, Duman CH, Duman RS (2018) Stress-induced neuronal CSF1 provokes microglia-mediated neuronal remodeling and depressive-like behavior. Biol Psychiatry 83:38-49. CrossRef Medline

Wood SK, Zhang XY, Reyes BA, Lee CS, Van Bockstaele EJ, Valentino RJ (2013) Cellular adaptations of dorsal raphe serotonin neurons associated with the development of active coping in response to social stress. Biol Psychiatry 73:1087-1094. CrossRef Medline

World Health Organization (2014) Global status report on alcohol and health. Geneva, Switzerland: World Health Organization. 